\title{
Mechanisms of fibroblast growth factor signaling in the ovarian follicle
}

\section{Christopher A Price}

Faculty of Veterinary Medicine, Centre de recherche en reproduction animale, University of Montreal, 3200 rue Sicotte, St-Hyacinthe, Quebec, Canada J2S 7C6
Correspondence should be addressed to C A Price Email

christopher.price@ umontreal.ca

\begin{abstract}
Fibroblast growth factors (FGFs) have been shown to alter growth and differentiation of reproductive tissues in a variety of species. Within the female reproductive tract, the effects of FGFs have been focused on the ovary, and the most studied one is FGF2, which stimulates granulosa cell proliferation and decreases differentiation (decreased steroidogenesis). Other FGFs have also been implicated in ovarian function, and this review summarizes the effects of members of two subfamilies on ovarian function; the FGF7 subfamily that also contains FGF10, and the FGF8 subfamily that also contains FGF18. There are data to suggest that FGF8 and FGF18 have distinct actions on granulosa cells, despite their apparent similar receptor binding properties. Studies of non-reproductive developmental biology also indicate that FGF8 is distinct from FGF18, and that FGF7 is also distinct from FGF10 despite similar receptor binding properties. In this review, the potential mechanisms of differential action of FGF7/FGF10 and FGF8/FGF18 during organogenesis will be reviewed and placed in the context of follicle development. A model is proposed in which FGF8 and FGF18 differentially activate receptors depending on the properties of the extracellular matrix in the follicle.
\end{abstract}

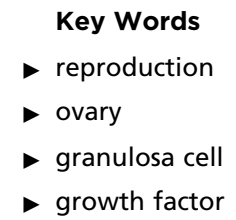

Journal of Endocrinology (2016) 228, R31-R43

\section{Introduction}

Development of the ovarian follicle from preantral to preovulatory stages is highly complex and involves multiple endocrine and paracrine signaling pathways. It is well known that the pituitary gonadotrophins are the main endocrine drivers of many stages of follicle development; however, it is becoming increasingly evident that several families of growth factors also play important roles within the follicle, including the insulin-like growth factor and transforming growth factor beta families (Knight \& Glister 2006, Sudo et al. 2007). A further growth factor family with potential paracrine actions contains the fibroblast growth factors (FGFs). In mammals, this family consists of 18 secreted proteins (and four intracellular proteins called FGF homologous factors) that are grouped into subfamilies based on sequence homology (Itoh \&
Ornitz 2004). It has been recognized for over 20 years that FGF2 acts on granulosa cells to promote cell proliferation and decrease apoptosis and steroidogenesis (Gospodarowicz \& Bialecki 1979, Baird \& Hsueh 1986, Lavranos et al. 1994, Vernon \& Spicer 1994), and over the last decade several other FGFs have been implicated in ovarian function and follicle development, as recently reviewed (Chaves et al. 2012).

The expression of some FGF family members in the ovary is tissue specific and others are widely expressed; for example, FGF7 is expressed in theca cells but not granulosa cells or oocytes (Parrott et al. 1994), whereas FGFR2 is readily detected in granulosa, cumulus and theca cells, and the oocyte (see Table 1 for a summary of the known expression patterns of FGF and FGFR genes).

Published by Bioscientifica Ltd. 
Table 1 Localization of FGF and FGFR mRNA in antral ovarian follicles. Where a cell type is not listed, the relevant gene is not expressed

\begin{tabular}{ll} 
Gene & Cell type \\
\hline FGF1 & $\begin{array}{l}\text { Theca }>\text { granulosa } \\
\text { Theca } \\
\text { FGF2 }\end{array}$ \\
FGF7 & $\begin{array}{l}\text { Theca } \\
\text { Oocyte } \\
\text { FGF8 }\end{array}$ \\
& Oocyte, theca, granulosa \\
FGF9 & Theca \\
& Theca, oocyte \\
FGF10 & Oocytes $\gg$ granulosa, theca \\
FGF17 & Theca \\
FGF18 & Cumulus, oocyte \\
FGFR1b & Cumulus, oocyte \\
FGFR1c & Granulosa, cumulus, oocyte \\
FGFR2b & Theca, granulosa, cumulus, oocyte \\
FGFR2c & Theca, granulosa, cumulus \\
FGFR3c & Granulosa \\
FGFR4 & Theca
\end{tabular}

\begin{tabular}{l} 
Species \\
\hline Cattle \\
Rat \\
Cattle \\
Mouse \\
Cattle \\
Rat \\
Cattle \\
Cattle \\
Cattle \\
Cattle \\
Cattle \\
Cattle \\
Cattle \\
Cattle \\
Cattle \\
Mouse \\
Cattle
\end{tabular}

\begin{tabular}{l} 
References $^{\text {a }}$ \\
\hline Berisha et al. (2004) \\
Koos \& Olson (1989) \\
Parrott et al. (1994) \\
Valve et al. (1997) \\
Buratini et al. (2005) \\
Drummond et al. (2007) \\
Grado-Ahuir et al. (2011) \\
Buratini et al. (2007) \\
Machado et al. (2009) \\
Portela et al. (2010) \\
Zhang \& Ealy (2012) \\
Zhang \& Ealy (2012) \\
Berisha et al. (2004) and Zhang \& Ealy (2012) \\
Berisha et al. (2004) and Zhang \& Ealy (2012) \\
Buratini et al. (2005) \\
Puscheck et al. (1997) \\
Buratini et al. (2005)
\end{tabular}

${ }^{a}$ References are given for the first major report of expression pattern of each gene in the species indicated. Multiple species are given only where localization differs.

A restricted pattern of expression of a ligand raises the possibility of targeted signaling to neighboring cells, a classic example of which is mesenchymal to epithelial cell signaling by FGFs during embryo development. In the context of the ovarian follicle, theca cells are mesenchymal and granulosa cells are epithelial, therefore paracrine FGFs may play a role in follicle development. The purpose of this review is to summarize recent information on the potential role in the follicle of members of two FGF subfamilies involved in mesenchymal to epithelial cell signaling, the FGF7 and FGF8 families. Studies with reproductive and non-reproductive tissues have suggested that members of these subfamilies have divergent actions on their target tissues, and potential mechanisms for the actions of FGF7 and FGF8 family members in the ovary will be discussed.

\section{FGFs and mesenchymal-epithelial cell signaling}

The structure and general function of FGFs has been well reviewed (Beenken \& Mohammadi 2009, Ornitz \& Itoh 2015). These ligands are grouped into subfamilies based on sequence homology and phylogeny (Itoh \& Ornitz 2004), and members of the same subfamily have similar receptor binding properties. Most FGFs are considered to be paracrine factors although the FGF19 subfamily (FGF19, FGF21, and FGF23) are endocrine factors with roles to play in cholesterol, vitamin $\mathrm{D}$, and phosphate homeostasis (see Beenken \& Mohammadi (2009) for review). Most FGF proteins possess signal peptides and are secreted through the conventional endoplasmic reticulum - Golgi pathway, although FGF1 and FGF2 are secreted through an unconventional pathway involving translocation through the cell membrane and binding to cell surface proteoglycans (Steringer et al. 2015). The association of paracrine FGFs to the extracellular matrix is of relevance here and will be discussed in more detail below.

The ligands are well conserved across mammalian species. It is worth noting at this point that FGF7, FGF10, FGF8, and FGF18 proteins are 95, 91, 98, and $100 \%$ homologous respectively between mice and cattle, the two species most commonly used in the studies described below.

The FGFs receptors (FGFR) are tyrosine kinase receptors that are derived from four main genes, FGFR1, FGFR2, FGFR3, and FGFR4. Alternative splicing events result in two variants of FGFR1, FGFR2, and FGFR3 proteins commonly termed the ' $\mathrm{b}$ ' and ' $\mathrm{c}$ ' forms, and these variants have markedly different ligand binding properties. For example, members of the FGF7 family (FGF3, FGF7, FGF10, and FGF22) activate the ' $b$ ' splice forms of FGFR1 and FGFR2 but not the ' $c$ ' splice variants, whereas many other FGFs activate the ' $c$ ' splice variants to different degrees (Zhang et al. 2006). For a detailed discussion of the molecular basis for ligand specificity see (Belov \& Mohammadi 2013). In general, 'b' splice variants of FGFR proteins are expressed in epithelial tissues

Published by Bioscientifica Ltd. 
and ' $c$ ' splice variants are expressed in mesenchymal cells (Orr-Urtreger et al. 1993), which sets the scene for potential paracrine signaling between these two cell types.

It has been recognized for some time that the biological activity of FGFs, as well as other growth factors, is dependent on interactions with the ECM (Kim et al. 2011). In order to activate their receptors, the paracrine FGFs need to bind to heparan sulfate (HS), which is a linear sulfated polysaccharide present within the ECM and on cell surfaces where it is linked to soluble (e.g. perlecan) or cell membrane bound proteins (e.g. syndecan, glypican) collectively known as HS proteoglycans (HSPG). Both FGF and FGFR bind to HS, which increases receptor binding affinity and stabilizes the FGF-FGFR complex (see Ornitz \& Itoh (2015) for review). The paracrine FGFs are inactive when applied to HSPG deficient cell lines (Yayon et al. 1991, Spivak-Kroizman et al. 1994, Loo \& Salmivirta 2002), and addition of heparin or HS restores biological activity. Mice null for key enzymes involved in elongation of HS chains fail to respond to FGF signaling (Shimokawa et al. 2011).

Mesenchymal-epithelial signaling by FGFs is most evident in organ development. In the developing limb, FGF10 secreted from the mesenchyme activates FGFR2b in the apical ectodermal ridge, which is a critical early step in formation of the limb bud. In the developing mouse lung, mesenchymal FGF10 activation of epithelial FGFR2b is essential for airway branching (Colvin et al. 2001), and mesenchymal FGF18 is essential for alveolar development, acting through epithelial FGFR2c (Usui et al. 2004). The pivotal early role of FGF10 signaling was demonstrated in FGFR2b knockout mice, which die at birth with severe defects of the limbs and lungs as well as salivary glands and other tissues (De Moerlooze et al. 2000). Knockout of FGF10 or FGF18 in mice is also lethal and results in severe abnormalities in both skeletal and lung development (Itoh \& Ornitz 2004).

An additional layer of fine control of organ development is exerted by important differences in biological activity of members of the same FGF subfamily. For example, FGF7 induces branching of epithelial limb buds whereas FGF10 induces bud elongation (Bellusci et al. 1997, Koyama et al. 2008, Makarenkova et al. 2009), and FGF18 stimulates expansion in the embryonic midbrain whereas FGF8 stimulates differentiation of the midbrain into cerebellum (Liu et al. 2003, Sato \& Nakamura 2004). These differences will be explored further later in this review.

Obviously, lungs and limbs develop once in mammals, whereas the post-natal ovary is a site of constant development of follicles from the resting pool of primordial follicles. These follicles consist of an immature oocyte surrounded by a single layer of squamous epithelial 'pre-granulosa' cells. To develop into growing follicles, the squamous pre-granulosa cells develop into cuboidal granulosa cells and proliferate, and the follicle acquires a layer of mesenchymal theca cells. As the antrum forms, cells of both epithelial and mesenchymal layers proliferate, and this is regulated in part by mesenchymalepithelial communications (Knight \& Glister 2006). Interestingly, certain features of FGF7 and FGF8 subfamily signaling in the follicle resemble those occurring during lung and limb development (Fig. 1), and while development of the preantral follicle would logically be most similar to development of the lung and limbs, there are very few studies of these FGFs in preantral follicles; mRNA and protein for both FGF7 and FGF10 have been reported in oocytes and granulosa cells of preantral follicles and in fetal ovaries in humans and cattle (Buratini et al. 2007, Abir et al. 2009, Oron et al. 2012, Castilho et al. 2014), and while FGFR3C mRNA was detected in secondary bovine

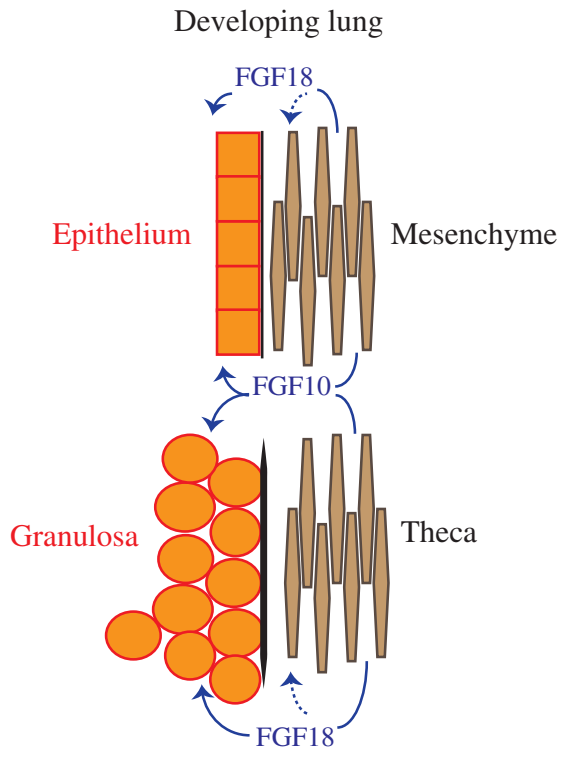

Developing follicle

\section{Figure 1}

FGF10 and FGF18 signaling in the developing follicle parallels FGF signaling in embryonic tubular organs. In both structures, the mesenchyme secretes FGF10 which acts on FGFR2b expressed exclusively in epithelial cells. The mesenchyme also secretes FGF18 which acts on FGFR2C/FGFR3C/FGFR4 in epithelial cells (solid line) and may also be able to activate the same receptors in mesenchymal cells (dotted line), although definitive evidence is lacking.

Published by Bioscientifica Ltd. 
follicles (Buratini et al. 2005), its cellular location has not been described.

There is much more information about the role of FGFs in mesenchymal-epithelial signaling in the antral follicle. Consistent with the pattern observed in organogenesis, FGF10 is expressed predominantly in theca (mesenchymal) cells (Buratini et al. 2007) and FGFR2b mRNA is detected predominantly in granulosa (epithelial) cells (Berisha et al. 2004). Messenger RNA encoding FGF18 is also detected in theca cells (Portela et al. 2010) although expression of FGFR2C and FGFR3c is detectable in both granulosa and theca cells (Berisha et al. 2004, Buratini et al. 2005). This is not inconsistent with the developmental change of expression of FGFR2c in the embryonic mouse, for which mRNA is detected only in the epithelium of very early lung and limb buds (Oldridge et al. 1999, Usui et al. 2004) and becomes detectable also in the mesenchyme after embryonic day 15 (Usui et al. 2004). Whether a similar shift in the pattern of expression of FGFR2c and FGFR3c occurs during development of the ovary or development of preantral follicles is not known.

\section{The role of the FGF7 family in follicle development}

Mesenchymal-epithelial signaling in the antral follicle was nicely demonstrated by Parrott et al. (1994) who first demonstrated that FGF7 is expressed in bovine theca but not in granulosa cells, and that it affects granulosa and not theca cells. These studies demonstrated the absence of functional FGFR2b in theca cells, which was later supported by PCR data (Berisha et al. 2004). Incubation of bovine or rat granulosa cells with FGF7 increased cell proliferation and decreased progesterone secretion and aromatase activity (Parrott \& Skinner 1998). Theca cell FGF7 mRNA abundance was higher in large compared with small and medium sized bovine follicles in one study (Parrott \& Skinner 1998), although a later study reported no affect of health status (based on follicular fluid oestradiol:progesterone ratio) on FGF7 mRNA levels (Buratini et al. 2007).

FGF10 has also been described in the antral follicle, and has a different pattern of expression compared with FGF7. Whereas FGF7 is restricted to the theca layer, FGF10 mRNA was identified in bovine theca cells and the oocyte (Buratini et al. 2007). It is interesting to note that both proteins have been detected in preantral follicles, which do not contain theca cells (Buratini et al. 2007, Abir et al. 2009, Oron et al. 2012, Castilho et al. 2014), thus a developmental switch in localization may occur once follicles become antral. Further, whereas FGF7 mRNA levels were not altered by follicle health in bovine follicles, FGF10 mRNA levels were significantly higher in theca cells from less oestrogenic (atretic) compared with highly oestrogenic follicles (Buratini et al. 2007).

As with FGF7, the addition of FGF10 to granulosa cells in vitro inhibited steroid secretion (Buratini et al. 2007). More interestingly, the injection of FGF10 directly into a growing follicle in cattle in vivo caused follicle regression and lowered the abundance of granulosa cell CYP19A1 mRNA (Gasperin et al. 2012).

The presence of FGF10 mRNA in the oocyte raised the question of a role of oocyte derived FGF10 in cumulus cell function and oocyte maturation. This was first explored by Zhang et al. (2010) who demonstrated that addition of exogenous FGF10 to bovine cumulus oocyte complexes during in vitro maturation (IVM) increased cumulus expansion and the rate of blastocyst development, and that immunoneutralizing endogenous FGF10 reduced cumulus expansion and the rate of blastocyst development. This latter observation is compelling evidence of endogenous FGF10 signaling within the follicle. It has since been shown that exogenous FGF10 stimulates glucose uptake by cumulus cells and decreases the level of apoptosis in oocytes during IVM (Caixeta et al. 2013, Pomini Pinto et al. 2015). Whether FGF7 would have the same effect is unknown.

The effects of FGF7 and of FGF10 on the in vitro growth of preantral follicles have been explored by several laboratories. In rats, FGF7 stimulated development of primary follicles (McGee et al. 1999, Kezele et al. 2005) but did not do so in goats (Faustino et al. 2011), whereas FGF10 stimulated primary follicle development in goats (Chaves et al. 2010). Whether these discrepancies are related to different culture conditions or species is unclear.

Very little is known about the role of the two remaining members of the FGF7 family in the ovary. Messenger RNA encoding FGF3 and FGF22 has been detected in mouse oocytes (Zhong et al. 2006), although any potential action on follicular cells has not been reported.

\section{The role of the FGF8 family in follicle development}

The FGF8 family consists of FGF17 and FGF18 in addition to the prototype FGF8. Messenger RNA encoding all three genes has been detected in mouse oocytes; in a microarray study, $F g f 8$ and $F g f 18$ were highly expressed in mouse oocytes whereas $F g f 17$ was weakly expressed (Zhong et al.

Published by Bioscientifica Ltd 
2006). Although $F g f 8$ mRNA was initially reported to be located exclusively in oocytes in the adult female mouse (Valve et al. 1997), another study reported transcripts in theca and granulosa cells in cattle (Schmitt et al. 1996, Zammit et al. 2002, Buratini et al. 2005). The main receptors for FGF8 subfamily members, FGFR3c and FGFR2c, have been localized to granulosa and theca cells in cattle (Berisha et al. 2004, Buratini et al. 2005).

Based on the presence of FGF8 mRNA in the mouse oocyte, the role of this growth factor in cumulus function was explored. In the mouse COC, removal of the oocyte prevents cumulus expansion and inhibits glycolysis in the cumulus cell. The replacement of denuded oocytes to cumulus cells reverses this effect (Sugiura et al. 2007). In a search for the oocyte derived factors that influence cumulus glycolysis, Sugiura et al. (2007) cultured oocytectomized cumulus cells with either the well known oocyte derived bone morphogenetic protein (BMP)- 15 or with FGF8, and while neither alone had an effect on cumulus glycolysis, when added together they stimulated glycolysis to levels observed in the presence of oocytes.

Also in the mouse, FGF8 was shown to inhibit oestradiol secretion and Cyp19a1 mRNA levels in granulosa cells, but had no effect on progesterone secretion (Miyoshi et al. 2010). Interestingly, single nucleotide polymorphisms have been detected in the bovine FGF8 gene that are correlated with the number of antral follicles (Santos-Biase et al. 2012), suggesting a potentially important role for FGF8 in regulating follicle activation or early development.

The effect of FGF17 and FGF18 on granulosa cells has been explored in cattle. FGF17 mRNA was detected mainly in oocytes with trace amounts in granulosa and theca cells (Machado et al. 2009), which is not dissimilar to the pattern of expression of FGF8 mRNA in this species. FGF17 protein was readily detected in oocytes and granulosa cells; addition of recombinant FGF17 to granulosa cells in vitro inhibited oestradiol and progesterone secretion (Machado et al. 2009). Similarly to FGF8, the restricted pattern of expression of FGF17 to the oocyte led to studies of a potential action in cumulus oocyte communication; addition of FGF17 increased the proportion of bovine COCs that fully expanded, but this did not improve the developmental competence of the oocyte (Machado et al. 2015).

The pattern of expression of FGF18 is more typical of the mesenchymal-epithelial signaling pathways of FGFs in general. Messenger RNA was not readily detected in the oocyte of cattle but is abundant in theca cells (Portela et al. 2010). Addition of recombinant FGF18 to bovine granulosa cells in vitro inhibited oestradiol and progesterone secretion, and lowered abundance of mRNA encoding major estrogenic and progestagenic enzymes (Portela et al. 2010). Unlike the known actions of other FGFs in the ovary, however, FGF18 appears to be a proapoptotic factor. Abundance of FGF18 mRNA and protein is higher in atretic compared with growing bovine follicles, and addition of FGF18 increased the amount of DNA laddering and caspase-3 activation in granulosa cells in vitro (Portela et al. 2010, 2015). The mechanisms of action of FGF18 in the follicle have not been fully elucidated, but it may act through a murine double minute 2 (MDM2) and p53 upregulated modulator of apoptosis (PUMA, also known as BBC3) pathway (Portela et al. 2015), although it has not yet been shown whether FGF18 alters p53 signaling. Most intriguingly, FGF18 does not result in the typical phosphorylation of MAPK3/1, but does phosphorylate MAPK14 (also known as p38); increased activity of MAPK14 has been linked to apoptosis in ovarian cells (Uma et al. 2003, Bu et al. 2006).

Proapoptotic actions of FGFs are rare but other examples exist, including the observation that FGF18 inhibited intestinal crypt cell proliferation, while inhibition of FGFR3 increased cell proliferation (ArnaudDabernat et al. 2008). Further, an activating mutation of FGFR3c led to increased granulosa cell apoptosis in mice (Amsterdam et al. 2001). Collectively, these data suggest that FGF18 activates an apoptotic pathway through FGFR3c in granulosa as well as some other cell types.

The ability of FGF18 but not of FGF8 to increase apoptosis raises an intriguing question: how do two ligands that activate the same receptors have such different effects on the target cell? To explore this question, one needs to understand the mechanism of FGF signaling, which is reviewed in the next section.

\section{Intracellular FGF signaling in granulosa cells}

The intracellular pathways used by FGFs have been elucidated in a variety of cell lines and have been well reviewed (Dailey et al. 2005, Cotton et al. 2008, Iwata \& Hevner 2009). In brief, upon binding to the ligand, the activated FGF receptor dimerizes and the resulting conformational change in the receptor structure causes autophosphorylation of specific tyrosine residues. Two main branches of signaling are then activated: phosphorylation of MAPK via phospholipase $\mathrm{C}$, and activation of phosphatidylinositol-3-kinase and subsequent Akt and protein kinase C (PKC) pathways. This results in expression of a number of early immediate response genes,

Published by Bioscientifica Ltd 
including the Sprouty (SPRY) family of negative regulators of tyrosine kinase receptors, and the nuclear orphan receptor $4 \mathrm{~A}$ and ETS families of transcription factors.

Most of these pathways have been demonstrated to be active in granulosa cells, mainly using FGF2 as a 'typical' FGF ligand. In rat granulosa cells, FGF2 stimulated calcium signaling through a PKC dependent pathway (Peluso et al. 2001), and in bovine granulosa cells FGF2 stimulated MAPK3/1 and Akt phosphorylation (Jiang et al. 2011). In human granulosa lutein cells, FGF2 but not FGF4 or FGF10 increased SPRY2 mRNA levels (Haimov-Kochman et al. 2005), whereas in bovine granulosa cells FGF2 and FGF4 stimulated SPRY2 mRNA abundance (Jiang et al. 2011, Jiang \& Price 2012). Several studies have demonstrated that FGF8 stimulates MAPK3/1 phosphorylation and SPRY2 mRNA levels in rat, human and mouse granulosa/ cumulus cells (Sugiura et al. 2009, Miyoshi et al. 2010, Jiang et al. 2013).

In a comparison of FGF8 and FGF18 signaling pathways in bovine granulosa cells, we demonstrated that FGF8 activates the typical FGF responses including phosphorylation of $\mathrm{MAPK} 3 / 1$ and rapid and transient expression of SPRY2 and NR4A2, whereas FGF18 altered none of these targets (Jiang et al. 2013). Using a microarray approach, we identified additional early immediate response genes that were upregulated by FGF8 but not by FGF18, including FOS and XIRP1, and others that were stimulated by both FGF8 and FGF18, including FOSL1 (Jiang et al. 2013). Perhaps the most interesting difference between FGF8 and FGF18 was the stimulation by FGF8 and marked inhibition by FGF18 of abundance of mRNA encoding the DNA damage response gene GADD45B. Decreased GADD45B expression has been linked to increased apoptosis in several cell types, and thus may be part of the mechanism used by FGF18 to increase apoptosis in granulosa cells. The known differences in the response of granulosa cells to FGF8 and FGF18 are summarized in Fig. 2.

\section{The basis for divergent signaling of related FGFs}

Collectively, the literature suggests potential roles for FGF7 and FGF8 family members in preantral and/or antral follicle growth and development, and that some FGFs of the same subfamily that activate the same receptors have markedly different biological effects on their target cells. Such differences between closely related FGFs have been described during embryo development, and these are especially pertinent to the present discussion as they are

\section{FGF2 FGF8 FGF18}

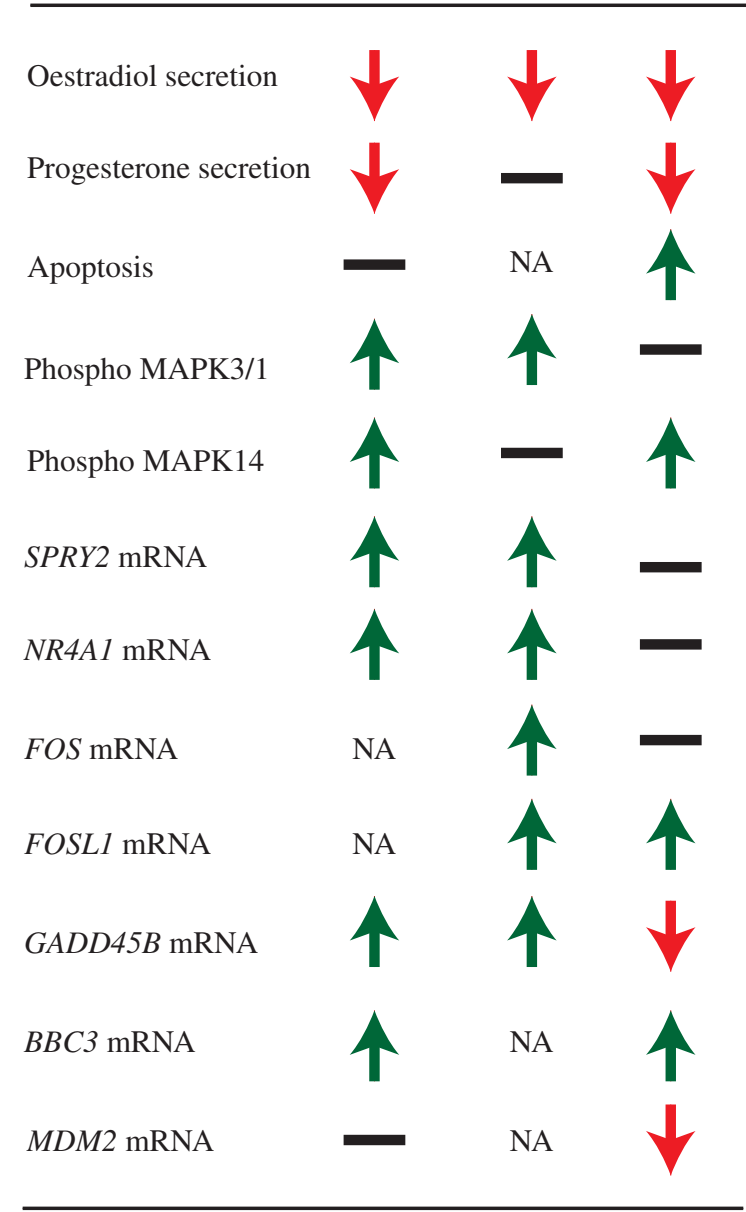

Figure 2

Schematic illustration of significant differences between the effects of FGF2, FGF8, and FGF18 on granulosa cell function (steroid secretion), health (apoptosis and abundance of $B B C 3, G A D D 45 B$, and MDM2 mRNA), intracellular signaling (phosphorylation of MAPK3/1 and MAPK14), and abundance of mRNA encoding early immediate (FOS, FOSL1) and FGF response (SPRY2, NR4A1) genes. Horizontal lines indicate no effect; NA, data not available. Data from Miyoshi et al. (2010), Jiang et al. $(2011,2013)$ and Portela et al. (2015).

FGF7 vs FGF10, and FGF8 vs FGF18. Branching morphogenesis refers to the growth and branching of tubular structures in tissues such as lung, kidney, and salivary glands. In these tissues, FGF7 and FGF10 play distinct roles; FGF7 induces expansion or branching of epithelial buds whereas FGF10 induces bud elongation (Bellusci et al. 1997, Koyama et al. 2008, Makarenkova et al. 2009). For the FGF8 subfamily, FGF18 stimulates expansion in the embryonic midbrain whereas FGF8 transforms the midbrain into cerebellum (Liu et al. 2003, Sato \& Nakamura 2004). The current literature suggests that these distinct biological activities may be directed by i) differential

Published by Bioscientifica Ltd 
intracellular signaling and/or ii) interactions between FGFs, FGFRs, and HSPGs.

\section{Differential intracellular signaling}

Distinct signaling between FGF7 and FGF10 in HeLa cells transfected with FGFR2b results in FGF7 increasing cell proliferation whereas FGF10 promotes cell migration. This has been correlated with sustained phosphorylation of MAPK3/1 by FGF7 but transient (or weak) phosphorylation by FGF10 (Koyama et al. 2008, Francavilla et al. 2013), owing to a difference in the pattern of tyrosine phosphorylation in the kinase domain of FGFR2b (Francavilla et al. 2013). In the embryonic mouse kidney and submandibular gland, FGF7 but not FGF10 induced expression of the FGF target gene Spry2 (Chi et al. 2004, Ohno et al. 2010), although other studies have shown increased Spry2 mRNA levels following treatment with FGF10 (Hashimoto et al. 2012). In bovine granulosa cells, FGF10 results in a slow activation of MAPK3/1 without stimulating the expression of SPRY2 mRNA levels (Jiang \& Price 2012).

A similar dichotomy occurs for members of the FGF8 subfamily, albeit with an extra layer of complexity. Messenger RNA encoding FGF8 but not FGF18 undergoes alternative splicing to generate proteins with different N-termini (Crossley \& Martin 1995). These splicing events result in a short form (FGF8a) and a longer form (FGF8b) among others, and it is recombinant FGF8b that has been used in studies of the ovary (Sugiura et al. 2007, Portela et al. 2015). FGF8a and FGF8b differ in their biological activities, as FGF8a induces expansion of the embryonic midbrain (in a manner similar to FGF18), whereas it is FGF8b that transforms the embryonic midbrain into a cerebellum (Liu et al. 2003, Sato \& Nakamura 2004). FGF8b provokes a strong activation of MAPK3/1 in the midbrain, whereas FGF8a results in a lower level of MAPK3/1 phosphorylation (Sato \& Nakamura 2004). Data from studies with bovine granulosa cells show that FGF8 results in a strong and transient phosphorylation of MAPK3/1 while addition of FGF18 provokes a very weak response (Jiang et al. 2013). The difference in the activities of FGF8a and FGF8b has been attributed to a single phenylalanine residue (F32) present in the N-terminus of FGF8b that allows strong binding with the receptor, and which is absent in FGF8a leading to a weak receptor binding complex (Olsen et al. 2006). However, this is not a satisfactory explanation of the difference between FGF8b and FGF18, as FGF18 contains the F32 residue present in FGF8b.
It is known that weak vs strong and transient vs sustained MAPK3/1 activation leads to distinct cell responses, driving cells toward proliferation or apoptosis in a cell context specific manner (Murphy et al. 2004, Glotin et al. 2006, Shaul \& Seger 2007). This may thus account in part for the differential responses of granulosa cells to FGF8 and FGF18.

\section{Interactions between FGFs, FGFRs and HSPGs}

FGF10 and FGF7 have been shown to bind to HSPGs (Bonneh-Barkay et al. 1997, Mongiat et al. 2000, Patel et al. 2007), and HS selectively alters the biological activity of FGF7/FGF10. In tissue explants, FGF7 and FGF10 have different binding affinities to the ECM, such that FGF7 diffuses readily through the ECM and reaches all cells in an explant, whereas FGF10 does not diffuse as well and reaches only those parts of an explant close to the source (Makarenkova et al. 2009). Addition of heparin to cultures of cell lines inhibits FGF7 mitogenic activity but stimulates that of FGF10 (Igarashi et al. 1998, Belleudi et al. 2007). Definitive evidence of the importance of HS in determining FGF7/FGF10 activity comes from a study in which the HS binding region FGF10 was mutated to that of FGF7 ( $\rightarrow \mathrm{V}$, see Fig. 3); one amino acid substitution converted FGF10 to a functional mimic of FGF7 (Makarenkova et al. 2009).

Sequence comparison between mouse and bovine proteins shows that the HS binding domain of FGF10 is fully conserved between species, whereas for FGF7 the

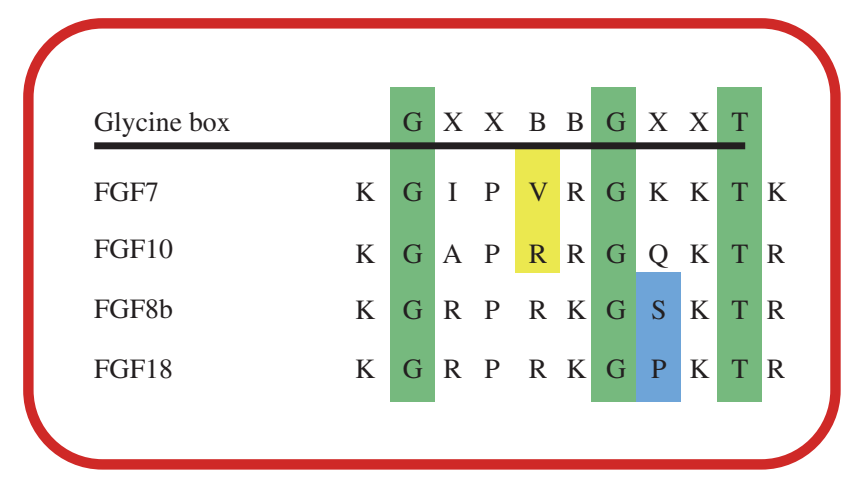

Figure 3

Sequence alignment of the HS binding domain ('glycine box') of paracrine FGFs $7,10,8 \mathrm{~b}$, and 18 . Green boxes denote residues from the core of the binding domain; the yellow box denotes residues that switch biological activity between FGF7 and FGF10, and the blue box illustrates the sequence difference between FGF8b and FGF18. Sequence data from Olsen et al. (2006) and Makarenkova et al. (2009). X, any residue, B, basic residue.

Published by Bioscientifica Ltd 
bovine sequence differs slightly $(\mathrm{I} \rightarrow \mathrm{V})$ but conserves the critical V.

HS is also essential for FGF8 subfamily signaling, as addition of FGF8 to HS deficient $\mathrm{CHO}$ cells did not stimulate cell proliferation or phosphorylation of MAPK3/1, whereas these activities were evident upon cotreatment with heparin (Loo \& Salmivirta 2002). Perlecan formed a ternary complex with FGF18 and FGFR3, and the presence of perlecan was essential for FGF18 induced proliferation of myeloid B cell lines (BaF32) expressing FGFR3 (Chuang et al. 2010). Whether sequence variation in the HS binding region accounts for different signaling between FGF8 and FGF18 has not been determined, although as they both possess the Arg residue that confers the biological activity of FGF10 (Fig. 3), this particular residue may not be a determinant of FGF8/FGF18 activity. The bovine and mouse FGF8 and FGF18 HS binding domains are fully conserved.

However, the presence or absence of HS is not the whole story, as the type of HS chain can also alter FGF biological activity. For example, perlecan derived from endothelial cells stimulated FGF18 induced proliferation of BaF32 cells to a much greater degree than did chondrocyte derived perlecan (Chuang et al. 2010). The type of HS also alters the ability of a FGF to activate a specific receptor, as short saccharide chains are sufficient to allow FGF1 to activate FGFR2b, whereas longer saccharide chains are required to allow FGF7 activation of FGFR2b (Ostrovsky et al. 2002). The ability of FGF10 to induce submandibular duct elongation or branching is dependent on the type of HS; 6-O-sulfated saccharides permit FGF10 induced elongation and the addition of 2-O-sulfated saccharides are required for branching (Patel et al. 2008).

FGF7 and FGF10 present a relatively simple situation in that they both activate one receptor. The situation is more complicated for FGF8 and FGF18, as they activate FGFR1c, FGFR2c, FGFR3c and FGFR4, and HS may alter affinity or activity of a specific ligand receptor pair; in mouse embryos, FGF8 binding to FGFR2c required 2-Oand 6-O-sulfated HS, whereas FGF8-FGFR3c binding required only 6-O-sulfated HS (Allen \& Rapraeger 2003). Whether the same requirements apply for FGF18 binding to FGFR2c vs FGFR3c is not known. Developmental regulation of the type and degree of HS sulfation may permit a temporal control over FGF bioactivity; the complexity of 6-O-sulfation in embryonic brain HS changes during development and this may restrict FGF8 action to a much more defined period during development (Brickman et al. 1998, Ford-Perriss et al. 2002).
The two explanations described above are not mutually exclusive, as the mechanism by which HS alters FGF-FGFR signaling may include differential phosphorylation of tyrosine residues within the receptor kinase domain of the receptor. A link between HSPG and receptor activity was demonstrated for FGF2, which alone is able to induce phosphorylation of certain residues of FGFR1 in HS deficient $\mathrm{CHO}$ cells, whereas co-treatment with heparin is required for phosphorylation of additional residues that lead to PLC activation (Lundin et al. 2003).

Collectively, these studies point clearly to a modification of specific FGF-FGFR activities by proteoglycans during development. How does this impact FGF signaling in the follicle? Antral follicles contain numerous proteoglycans and granulosa cells produce HSPG (Yanagishita \& Hascall 1983, McArthur et al. 2000). Theca cells are separated from granulosa cells by a basement membrane, which contains perlecan as well as other components, and the levels of these components change with follicle growth (Rodgers et al. 2003). In addition, a particular form of extracellular matrix (focimatrix) occurs as aggregates within the granulosa cell layer and which contains perlecan (Irving-Rodgers et al. 2004). Perlecan mRNA levels change during follicle development (Matti et al. 2010), and HSPG levels within the granulosa cell layer, likely in focimatrix, are significantly higher in atretic compared with healthy follicles (Huet et al. 1997, 1998, Irving-Rodgers et al. 2004, Matti et al. 2010). Further, follicle HSPG is sulfated and, at least in the cow, the quantity of certain sulfated HS derived saccharides change during follicle development and atresia (Hatzirodos et al. 2012). Therefore the potential for regulation of FGF signaling by follicular HSPGs exists.

How the ECM impacts FGF signaling in the follicle is unknown, but parallels can be drawn with the literature reviewed above. For example, it may be relatively easy for thecal FGF7 to cross the basement membrane and reach granulosa cells, but the passage of FGF10 may be restricted such that its influence is felt mainly by the layer of granulosa cells most closely associated with the basement membrane. Aggregates of focimatrix may play a role in regulating FGF10 or FGF18 bioactivity within the granulosa cell layer, and changes in sulfation of perlecan HS during follicle growth/atresia may diminish or enhance the potential pro-apoptotic actions of FGF18.

\section{Concluding remarks and future directions}

FGF signaling in developing tissues is highly regulated at multiple levels: gene transcription, alternative splicing,

Published by Bioscientifica Ltd 
activation of distinct intracellular pathways and the presence of specific sulfation patterns on target cell ECM proteins. In the ovary, FGF7 and FGF10 may have different effects on preantral follicle development, and FGF8 has markedly different effects on granulosa cells compared with FGF18. Although FGF7 and FGF10 bind to the same receptor, FGFR2b, they have different affinities for HS that causes a divergence of receptor phosphorylation events between these two ligands. Similarly for FGF8 subfamily members, observed differences of biological effects of FGF8 and FGF18 on granulosa cells may be related to the nature of sulfation of granulosa cell HSPGs. Extrapolating from studies in limb and lung development, a hypothetical model for the actions of FGF8 and FGF18 is presented in Fig. 4, in which FGF8 associates with 2-O- and 6-O-sulfated HS to phosphorylate multiple tyrosines in the kinase domain of the receptor, maybe predominantly FGFR2c leading to MAPK3/1 and MAPK14 activation (among others) and the typical FGF response. In contrast, FGF18 may associate with mainly (or different) 6-O-sulfated HS and phosphorylate fewer or different tyrosine residues in FGFR3c, leading to activation of pro-apoptotic MAPK14 without the activation of anti-apoptotic MAPK3/1, which in turn drives the cell toward caspase-3 mediated apoptosis.

Further research is required i) to identify the specific 2-O- or 6-O-sulfated saccharides present in focimatrix or other components of the granulosa cell ECM, and whether these change during follicle development and atresia; ii) to determine which receptors are activated by FGF18 vs FGF8 in granulosa cells, FGFR2c or FGFR3c; iii) to identify the specific receptor phosphorylation sites activated by FGF8 and FGF18 in granulosa cells; and iv) identify the upstream intracellular events that direct FGF8/FGF18 signaling to MAPK3/1 and /or MAPK14. The cumulus cell should not be forgotten, as in the mouse Fgf8 plays an important role in metabolism; further studies should

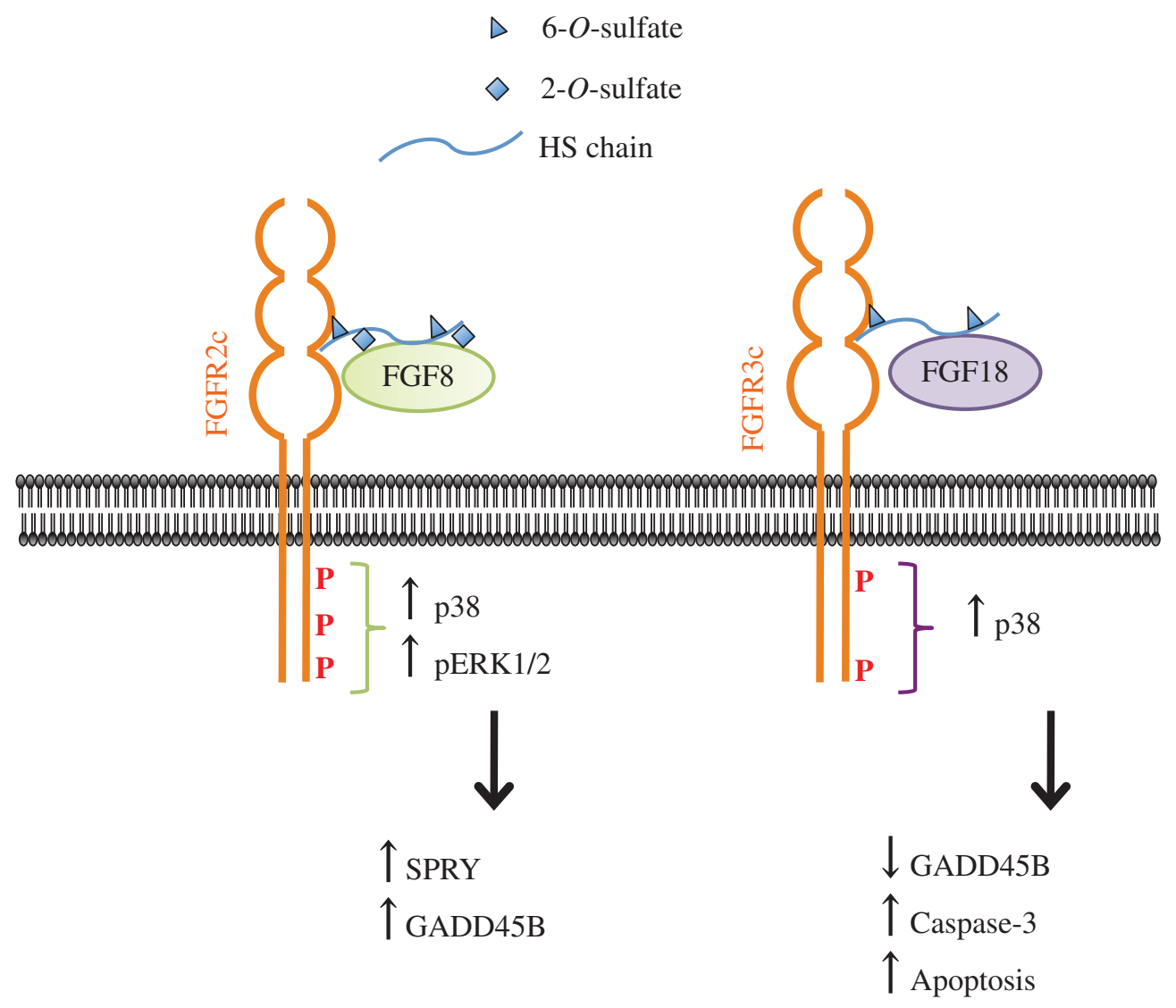

Figure 4

A hypothetical model of divergent signaling of FGF8 and FGF18 in granulosa cells, extrapolated from studies of branching morphogenesis. In this model, FGF8 associates with 2-O- and 6-O-sulfated HS to phosphorylate multiple tyrosines in the kinase domain of the receptor, predominantly FGFR2c, leading to MAPK3/1 (ERK1/2) and MAPK14 (p38) activation (among others) and the typical FGF response. In contrast, FGF18 phosphorylates

fewer or different tyrosine residues, leading to activation of pro-apoptotic p38 without the activation of anti-apoptotic ERK1/2, which in turn drives the cell toward caspase-3 mediated apoptosis; this distinct signaling pathway may be associated with an affinity to mainly 6-O-sulfated HS and activation of predominantly FGFR3c. 
explore the role of FGF18 in cumulus function. This information will shed new light on the role of FGF18 as an atypical pro-apoptotic FGF, and potentially lead to approaches to modify FGF18 activity and improve fertility in species such as cattle and humans.

\section{Declaration of interest}

The authors declare that there is no conflict of interest that could be perceived as prejudicing the impartiality of this review.

\section{Funding}

The Natural Science and Engineering Research Council (NSERC) of Canada.

\section{Acknowledgements}

I wish to acknowledge the Natural Science and Engineering Research Council (NSERC) of Canada for funding studies reported from my lab, and my thanks to Dina Ron for constructive comments on this manuscript.

\section{References}

Abir R, Fisch B, Zhang XY, Felz C, Kessler-Icekson G, Krissi H, Nitke S \& Ao A 2009 Keratinocyte growth factor and its receptor in human ovaries from fetuses, girls and women. Molecular Human Reproduction 15 69-75. (doi:10.1093/molehr/gan080)

Allen BL \& Rapraeger AC 2003 Spatial and temporal expression of heparan sulfate in mouse development regulates FGF and FGF receptor assembly. Journal of Cell Biology 163 637-648. (doi:10.1083/jcb. 200307053)

Amsterdam A, Kannan K, Givol D, Yoshida Y, Tajima K \& Dantes A 2001 Apoptosis of granulosa cells and female infertility in achondroplastic mice expressing mutant fibroblast growth factor receptor 3G374R. Molecular Endocrinology 15 1610-1623. (doi:10.1210/mend.15.9.0700)

Arnaud-Dabernat S, Yadav D \& Sarvetnick N 2008 FGFR3 contributes to intestinal crypt cell growth arrest. Journal of Cellular Physiology 216 261-268. (doi:10.1002/jcp.21401)

Baird A \& Hsueh AJ 1986 Fibroblast growth factor as an intraovarian hormone: differential regulation of steroidogenesis by an angiogenic factor. Regulatory Peptides 16 243-250. (doi:10.1016/01670115(86)90023-6)

Beenken A \& Mohammadi M 2009 The FGF family: biology, pathophysiology and therapy. Nature Reviews. Drug Discovery 8 235-253. (doi:10.1038/nrd2792)

Belleudi F, Leone L, Nobili V, Raffa S, Francescangeli F, Maggio M, Morrone S, Marchese C \& Torrisi MR 2007 Keratinocyte growth factor receptor ligands target the receptor to different intracellular pathways. Traffic 8 1854-1872. (doi:10.1111/j.1600-0854.2007.00651.x)

Bellusci S, Grindley J, Emoto H, Itoh N \& Hogan BL 1997 Fibroblast growth factor 10 (FGF10) and branching morphogenesis in the embryonic mouse lung. Development 124 4867-4878.

Belov AA \& Mohammadi M 2013 Molecular mechanisms of fibroblast growth factor signaling in physiology and pathology. Cold Spring Harbor Perspectives in Biology 5 a015958. (doi:10.1101/cshperspect.a015958)

Berisha B, Sinowatz F \& Schams D 2004 Expression and localization of fibroblast growth factor (FGF) family members during the final growth of bovine ovarian follicles. Molecular Reproduction and Development 67 162-171. (doi:10.1002/mrd.10386)
Bonneh-Barkay D, Shlissel M, Berman B, Shaoul E, Admon A, Vlodavsky I, Carey DJ, Asundi VK, Reich-Slotky R \& Ron D 1997 Identification of glypican as a dual modulator of the biological activity of fibroblast growth factors. Journal of Biological Chemistry 272 12415-12421. (doi:10.1074/jbc.272.19.12415)

Brickman YG, Ford MD, Gallagher JT, Nurcombe V, Bartlett PF \& Turnbull JE 1998 Structural modification of fibroblast growth factor-binding heparan sulfate at a determinative stage of neural development. Journal of Biological Chemistry 273 4350-4359. (doi:10.1074/jbc.273.8.4350)

Bu SZ, Huang Q, Jiang YM, Min HB, Hou Y, Guo ZY, Wei JF, Wang JW, Ni X $\&$ Zheng SS 2006 p38 Mitogen-activated protein kinases is required for counteraction of 2-methoxyestradiol to estradiol-stimulated cell proliferation and induction of apoptosis in ovarian carcinoma cells via phosphorylation Bcl-2. Apoptosis 11 413-425. (doi:10.1007/s10495006-4064-z)

Buratini J Jr, Teixeira AB, Costa IB, Glapinski VF, Pinto MGL, Giometti IC, Barros CM, Cao M, Nicola ES \& Price CA 2005 Expression of fibroblast growth factor- 8 and regulation of cognate receptors, fibroblast growth factor receptor (FGFR)-3c and -4 , in bovine antral follicles. Reproduction 130 343-350. (doi:10.1530/rep.1.00642)

Buratini J Jr, Pinto MGL, Castilho AC, Amorim RL, Giometti IC, Portela VM, Nicola ES \& Price CA 2007 Expression and function of fibroblast growth factor 10 and its receptor, fibroblast growth factor receptor $2 \mathrm{~B}$, in bovine follicles. Biology of Reproduction 77 743-750. (doi:10.1095/ biolreprod.107.062273)

Caixeta ES, Sutton-McDowall ML, Gilchrist RB, Thompson JG, Price CA, Machado MF, Lima PF \& Buratini J 2013 Bone morphogenetic protein 15 and fibroblast growth factor 10 enhance cumulus expansion, glucose uptake, and expression of genes in the ovulatory cascade during in vitro maturation of bovine cumulus-oocyte complexes. Reproduction 146 27-35. (doi:10.1530/REP-13-0079)

Castilho AC, da Silva RB, Price CA, Machado MF, Amorim RL \& Buratini J 2014 Expression of fibroblast growth factor 10 and cognate receptors in the developing bovine ovary. Theriogenology 81 1268-1274. (doi:10.1016/j.theriogenology.2014.02.008)

Chaves RN, Lima-Verde IB, Celestino JJH, Duarte ABG, Alves AMCV, Matos MHT, Campello CC, Name KPO, Báo SN, Buratini J Jr et al. 2010 Fibroblast growth factor-10 maintains the survival and promotes the growth of cultured goat preantral follicles. Domestic Animal Endocrinology 39 249-258. (doi:10.1016/j.domaniend.2010.06.006)

Chaves RN, Tavares de Matos MH, Buratini J \& Ricardo de Figueiredo J 2012 The fibroblast growth factor family: involvement in the regulation of folliculogenesis. Reproduction, Fertility, and Development 24 905-915. (doi:10.1071/RD11318)

Chi L, Zhang S, Lin Y, Prunskaite-Hyyryläinen R, Vuolteenaho R, Itäranta P \& Vainio S 2004 Sprouty proteins regulate ureteric branching by coordinating reciprocal epithelial Wnt11, mesenchymal Gdnf and stromal Fgf7 signalling during kidney development. Development 131 3345-3356. (doi:10.1242/dev.01200)

Chuang CY, Lord MS, Melrose J, Rees MD, Knox SM, Freeman C, Iozzo RV \& Whitelock JM 2010 Heparan sulfate-dependent signaling of fibroblast growth factor 18 by chondrocyte-derived perlecan. Biochemistry 49 5524-5532. (doi:10.1021/bi1005199)

Colvin JS, White AC, Pratt SJ \& Ornitz DM 2001 Lung hypoplasia and neonatal death in Fgf9-null mice identify this gene as an essential regulator of lung mesenchyme. Development 128 2095-2106.

Cotton LM, O'Bryan MK \& Hinton BT 2008 Cellular signaling by fibroblast growth factors (FGFs) and their receptors (FGFRs) in male reproduction. Endocrine Reviews 29 193-216. (doi:10.1210/er.2007-0028)

Crossley PH \& Martin GR 1995 The mouse Fgf8 gene encodes a family of polypeptides and is expressed in regions that direct outgrowth and patterning in the developing embryo. Development 121 439-451.

Dailey L, Ambrosetti D, Mansukhani A \& Basilico C 2005 Mechanisms underlying differential responses to FGF signaling. Cytokine and Growth Factor Reviews 16 233-247. (doi:10.1016/j.cytogfr.2005.01.007) 
De Moerlooze L, Spencer-Dene B, Revest J, Hajihosseini M, Rosewell I \& Dickson C 2000 An important role for the IIIb isoform of fibroblast growth factor receptor 2 (FGFR2) in mesenchymal-epithelial signalling during mouse organogenesis. Development 127 483-492.

Drummond AE, Tellbach M, Dyson M \& Findlay JK 2007 Fibroblast growth factor-9, a local regulator of ovarian function. Endocrinology 148 3711-3721. (doi:10.1210/en.2006-1668)

Faustino LR, Rossetto R, Lima IMT, Silva CMG, Saraiva MVA, Lima LF, Silva AWB, Donato MAM, Campello CC, Peixoto CA et al. 2011 Expression of keratinocyte growth factor in goat ovaries and its effects on preantral follicles within cultured ovarian cortex. Reproductive Sciences 18 1222-1229. (doi:10.1177/1933719111410709)

Ford-Perriss M, Guimond SE, Greferath U, Kita M, Grobe K, Habuchi H, Kimata K, Esko JD, Murphy M \& Turnbull JE 2002 Variant heparan sulfates synthesized in developing mouse brain differentially regulate FGF signaling. Glycobiology 12 721-727. (doi:10.1093/glycob/cwf072)

Francavilla C, Rigbolt Kristoffer TG, Emdal Kristina B, Carraro G, Vernet E, Bekker-Jensen Dorte B, Streicher W, Wikström M, Sundström M, Bellusci S et al. 2013 Functional proteomics defines the molecular switch underlying FGF receptor trafficking and cellular outputs. Molecular Cell 51 707-722. (doi:10.1016/j.molcel.2013.08.002)

Gasperin BG, Ferreira R, Rovani MT, Santos JT, Buratini J, Price CA \& Goncalves PB 2012 FGF10 inhibits dominant follicle growth and estradiol secretion in vivo in cattle. Reproduction 143 815-823. (doi:10.1530/REP-11-0483)

Glotin A-L, Calipel A, Brossas J-Y, Faussat A-M, Tréton J \& Mascarelli F 2006 Sustained versus transient ERK1/2 signaling underlies the anti- and proapoptotic effects of oxidative stress in human RPE cells. Investigative Ophthalmology \& Visual Science 47 4614-4623. (doi:10.1167/ iovs.06-0297)

Gospodarowicz D \& Bialecki H 1979 Fibroblast and epidermal growth factors are mitogenic agents for cultured granulosa cells of rodent, porcine, and human origin. Endocrinology 104 757-764. (doi:10.1210/ endo-104-3-757)

Grado-Ahuir JA, Aad PY \& Spicer LJ 2011 New insights into the pathogenesis of cystic follicles in cattle: microarray analysis of gene expression in granulosa cells. Journal of Animal Science 89 1769-1786. (doi:10.2527/jas.2010-3463)

Haimov-Kochman R, Ravhon A, Prus D, Greenfield C, Finci-Yeheskel Z, D SG-W, Natanson-Yaron S, Reich R, Yagel S \& Hurwitz A 2005 Expression and regulation of Sprouty-2 in the granulosa-lutein cells of the corpus luteum. Molecular Human Reproduction 11 537-542. (doi:10.1093/molehr/gah203)

Hashimoto S, Nakano H, Suguta Y, Irie S, Jianhua L \& Katyal SL 2012 Exogenous fibroblast growth factor-10 induces cystic lung development with altered target gene expression in the presence of heparin in cultures of embryonic rat lung. Pathobiology 79 127-143. (doi:10.1159/000334839)

Hatzirodos N, Nigro J, Irving-Rodgers HF, Vashi AV, Hummitzsch K, Caterson B, Sullivan TR \& Rodgers RJ 2012 Glycomic analyses of ovarian follicles during development and atresia. Matrix Biology 31 45-56. (doi:10.1016/j.matbio.2011.10.002)

Huet C, Monget P, Pisselet C \& Monniaux D 1997 Changes in extracellular matrix components and steroidogenic enzymes during growth and atresia of antral ovarian follicles in the sheep. Biology of Reproduction $\mathbf{5 6}$ 1025-1034. (doi:10.1095/biolreprod56.4.1025)

Huet C, Monget P, Pisselet C, Hennequet C, Locatelli A \& Monniaux D 1998 Chronology of events accompanying follicular atresia in hypophysectomized ewes. Changes in levels of steroidogenic enzymes, connexin 43 , insulin-like growth factor II/mannose 6 phosphate receptor, extracellular matrix components, and matrix metalloproteinases. Biology of Reproduction 58 175-185. (doi:10.1095/biolreprod58.1.175)

Igarashi M, Finch PW \& Aaronson SA 1998 Characterization of recombinant human fibroblast growth factor (FGF)-10 reveals functional similarities with keratinocyte growth factor (FGF-7). Journal of Biological Chemistry 273 13230-13235. (doi:10.1074/jbc.273.21.13230)
Irving-Rodgers HF, Harland ML \& Rodgers RJ 2004 A novel basal lamina matrix of the stratified epithelium of the ovarian follicle. Matrix Biology 23 207-217. (doi:10.1016/j.matbio.2004.05.008)

Itoh N \& Ornitz DM 2004 Evolution of the Fgf and Fgfr gene families. Trends in Genetics 20 563-569. (doi:10.1016/j.tig.2004.08.007)

Iwata T \& Hevner RF 2009 Fibroblast growth factor signaling in development of the cerebral cortex. Development, Growth \& Differentiation 51 299-323. (doi:10.1111/j.1440-169X.2009.01104.x)

Jiang Z \& Price C 2012 Differential actions of fibroblast growth factors on intracellular pathways and target gene expression in bovine ovarian granulosa cells. Reproduction 144 625-632. (doi:10.1530/REP-12-0199)

Jiang ZL, Ripamonte P, Buratini J, Portela VM \& Price CA 2011 Fibroblast growth factor-2 regulation of Sprouty and NR4A genes in bovine ovarian granulosa cells. Journal of Cellular Physiology 226 1820-1827. (doi:10.1002/jcp.22509)

Jiang Z, Guerrero-Netro HM, Juengel JL \& Price CA 2013 Divergence of intracellular signaling pathways and early response genes of two closely related fibroblast growth factors, FGF8 and FGF18, in bovine ovarian granulosa cells. Molecular and Cellular Endocrinology 375 97-105. (doi:10.1016/j.mce.2013.05.017)

Kezele P, Nilsson EE \& Skinner MK 2005 Keratinocyte growth factor acts as a mesenchymal factor that promotes ovarian primordial to primary follicle transition. Biology of Reproduction 73 967-973. (doi:10.1095/biolreprod.105.043117)

Kim S-H, Turnbull J \& Guimond S 2011 Extracellular matrix and cell signalling: the dynamic cooperation of integrin, proteoglycan and growth factor receptor. Journal of Endocrinology 209 139-151. (doi:10.1530/JOE-10-0377)

Knight PG \& Glister C 2006 TGF $\beta$ superfamily members and ovarian follicle development. Reproduction 132 191-206. (doi:10.1530/rep.1.01074)

Koos RD \& Olson CE 1989 Expression of basic fibroblast growth factor in the rat ovary: detection of mRNA using reverse transcriptionpolymerase chain reaction amplification. Molecular Endocrinology 3 2041-2048. (doi:10.1210/mend-3-12-2041)

Koyama N, Hayashi T, Ohno K, Siu L, Gresik EW \& Kashimata M 2008 Signaling pathways activated by epidermal growth factor receptor or fibroblast growth factor receptor differentially regulate branching morphogenesis in fetal mouse submandibular glands. Development, Growth \& Differentiation 50 565-576.

Lavranos TC, Rodgers HF, Bertoncello I \& Rodgers RJ 1994 Anchorageindependent culture of bovine granulosa cells: the effects of basic fibroblast growth factor and dibutyryl cAMP on cell division and differentiation. Experimental Cell Research $211245-251$. (doi:10.1006/excr.1994.1084)

Liu A, Li JYH, Bromleigh C, Lao Z, Niswander LA \& Joyner AL 2003 FGF17b and FGF18 have different midbrain regulatory properties from FGF8b or activated FGF receptors. Development $1306175-6185$. (doi:10.1242/dev.00845)

Loo B-M \& Salmivirta M 2002 Heparin/heparan sulfate domains in binding and signaling of fibroblast growth factor $8 \mathrm{~b}$. Journal of Biological Chemistry 277 32616-32623. (doi:10.1074/jbc.M204961200)

Lundin L, Ronnstrand L, Cross M, Hellberg C, Lindahl U \& Claesson-Welsh L 2003 Differential tyrosine phosphorylation of fibroblast growth factor (FGF) receptor-1 and receptor proximal signal transduction in response to FGF-2 and heparin. Experimental Cell Research 287 190-198. (doi:10.1016/S0014-4827(03)00125-3)

Machado MF, Portela VM, Price CA, Costa IB, Ripamonte P, Amorim RL \& Buratini J Jr 2009 Regulation and action of fibroblast growth factor 17 in bovine follicles. Journal of Endocrinology 202 347-353. (doi:10.1677/ JOE-09-0145)

Machado MF, Caixeta ES, Sudiman J, Gilchrist RB, Thompson JG, Lima PF, Price CA \& Buratini J 2015 Fibroblast growth factor 17 and bone morphogenetic protein 15 enhance cumulus expansion and improve quality of in vitro - produced embryos in cattle. Theriogenology $\mathbf{8 4}$ 390-398. (doi:10.1016/j.theriogenology.2015.03.031) 
Makarenkova HP, Hoffman MP, Beenken A, Eliseenkova AV, Meech R, Tsau C, Patel VN, Lang RA \& Mohammadi M 2009 Differential interactions of FGFs with heparan sulfate control gradient formation and branching morphogenesis. Science Signaling 2 ra55. (doi:10.1126/scisignal.2000304)

Matti N, Irving-Rodgers HF, Hatzirodos N, Sullivan TR \& Rodgers RJ 2010 Differential expression of focimatrix and steroidogenic enzymes before size deviation during waves of follicular development in bovine ovarian follicles. Molecular and Cellular Endocrinology 321 207-214. (doi:10.1016/j.mce.2010.02.019)

McArthur ME, Irving-Rodgers HF, Byers S \& Rodgers RJ 2000 Identification and immunolocalization of decorin, versican, perlecan, nidogen, and chondroitin sulfate proteoglycans in bovine small-antral ovarian follicles. Biology of Reproduction 63 913-924. (doi:10.1095/biolreprod63. 3.913)

McGee EA, Chun SY, Lai S, He Y \& Hsueh AJ 1999 Keratinocyte growth factor promotes the survival, growth, and differentiation of preantral ovarian follicles. Fertility and Sterility 71 732-738. (doi:10.1016/ S0015-0282(98)00547-0)

Miyoshi T, Otsuka F, Yamashita M, Inagaki K, Nakamura E, Tsukamoto N, Takeda M, Suzuki J \& Makino H 2010 Functional relationship between fibroblast growth factor-8 and bone morphogenetic proteins in regulating steroidogenesis by rat granulosa cells. Molecular and Cellular Endocrinology 325 84-92. (doi:10.1016/j.mce.2010.04.012)

Mongiat M, Taylor K, Otto J, Aho S, Uitto J, Whitelock JM \& Iozzo RV 2000 The protein core of the proteoglycan perlecan binds specifically to fibroblast growth factor-7. Journal of Biological Chemistry 275 7095-7100. (doi:10.1074/jbc.275.10.7095)

Murphy LO, MacKeigan JP \& Blenis J 2004 A network of immediate early gene products propagates subtle differences in mitogen-activated protein kinase signal amplitude and duration. Molecular and Cellular Biology 24 144-153. (doi:10.1128/MCB.24.1.144-153.2004)

Ohno K, Koyama N, Hayashi T, Takai Y, Gresik EW \& Kashimata M 2010 Regulation of expression of sprouty isoforms by EGF, FGF7 or FGF10 in fetal mouse submandibular glands. International Journal of Oral Science $\mathbf{7}$ 47-55. (doi:10.1016/S1348-8643(10)80002-3)

Oldridge M, Zackai EH, McDonald-McGinn DM, Iseki S, Morriss-Kay GM, Twigg SRF, Johnson D, Wall SA, Jiang W, Theda C et al. 1999 De novo alu-element insertions in FGFR2 identify a distinct pathological basis for Apert syndrome. American Journal of Human Genetics 64 446-461. (doi:10.1086/302245)

Olsen SK, Li JYH, Bromleigh C, Eliseenkova AV, Ibrahimi OA, Lao Z, Zhang F, Linhardt RJ, Joyner AL \& Mohammadi M 2006 Structural basis by which alternative splicing modulates the organizer activity of FGF8 in the brain. Genes and Development 20 185-198. (doi:10.1101/gad. 1365406)

Ornitz DM \& Itoh N 2015 The fibroblast growth factor signaling pathway. Wiley Interdisciplinary Reviews. Developmental Biology 4 215-266. (doi:10.1002/wdev.176)

Oron G, Fisch B, Zhang XY, Gabbay-Benziv R, Kessler-Icekson G, Krissi H, Ben-Haroush A, Ao A \& Abir R 2012 Fibroblast growth factor 10 in human ovaries. Reproductive Biomedicine Online 25 396-401. (doi:10.1016/j.rbmo.2012.07.002)

Orr-Urtreger A, Bedford MT, Burakova T, Arman E, Zimmer Y, Yayon A, Givol D \& Lonai P 1993 Developmental localization of the splicing alternatives of fibroblast growth factor receptor-2 (FGFR2). Developmental Biology 158 475-486. (doi:10.1006/ dbio.1993.1205)

Ostrovsky O, Berman B, Gallagher J, Mulloy B, Fernig DG, Delehedde M \& Ron D 2002 Differential effects of heparin saccharides on the formation of specific fibroblast growth factor (FGF) and FGF receptor complexes. Journal of Biological Chemistry 277 2444-2453. (doi:10.1074/jbc. M108540200)

Parrott JA \& Skinner MK 1998 Developmental and hormonal regulation of keratinocyte growth factor expression and action in the ovarian follicle. Endocrinology 139 228-235. (doi:10.1210/endo.139.1.5680)
Parrott JA, Vigne JL, Chu BZ \& Skinner MK 1994 Mesenchymal-epithelial interactions in the ovarian follicle involve keratinocyte and hepatocyte growth factor production by thecal cells and their action on granulosa cells. Endocrinology 135 569-575. (doi:10.1210/endo.139.1.5680)

Patel VN, Knox SM, Likar KM, Lathrop CA, Hossain R, Eftekhari S, Whitelock JM, Elkin M, Vlodavsky I \& Hoffman MP 2007 Heparanase cleavage of perlecan heparan sulfate modulates FGF10 activity during ex vivo submandibular gland branching morphogenesis. Development 134 4177-4186. (doi:10.1242/dev.011171)

Patel VN, Likar KM, Zisman-Rozen S, Cowherd SN, Lassiter KS, Sher I, Yates EA, Turnbull JE, Ron D \& Hoffman MP 2008 Specific heparan sulfate structures modulate FGF10-mediated submandibular gland epithelial morphogenesis and differentiation. Journal of Biological Chemistry 283 9308-9317. (doi:10.1074/jbc.M709995200)

Peluso JJ, Pappalardo A \& Fernandez G 2001 Basic fibroblast growth factor maintains calcium homeostasis and granulosa cell viability by stimulating calcium efflux via a PKC delta-dependent pathway. Endocrinology 142 4203-4211. (doi:10.1210/endo.142.10.8460)

Pomini Pinto RF, Fontes PK, Loureiro B, Sousa Castilho AC, Sousa Ticianelli J, Montanari Razza E, Satrapa RA, Buratini J \& Moraes Barros C 2015 Effects of FGF10 on bovine oocyte meiosis progression, apoptosis, embryo development and relative abundance of developmentally important genes in vitro. Reproduction in Domestic Animals 50 84-90. (doi:10.1111/ rda.12452)

Portela VM, Machado M, Buratini J Jr, Zamberlam G, Amorim RL, Goncalves P \& Price CA 2010 Expression and function of fibroblast growth factor 18 in the ovarian follicle in cattle. Biology of Reproduction 83 339-346. (doi:10.1095/biolreprod.110.084277)

Portela VM, Dirandeh E, Guerrero-Netro HM, Zamberlam G, Barreta MH, Goetten AF \& Price CA 2015 The role of fibroblast growth factor-18 in follicular atresia in cattle. Biology of Reproduction 92 14, 11-18. (doi:10.1095/biolreprod.114.121376)

Puscheck EE, Patel Y \& Rappolee DA 1997 Fibroblast growth factor receptor (FGFR)-4, but not FGFR-3 is expressed in the pregnant ovary. Molecular and Cellular Endocrinology 132 169-176. (doi:10.1016/S03037207(97)00131-7)

Rodgers RJ, Irving-Rodgers HF \& Russell DL 2003 Extracellular matrix of the developing ovarian follicle. Reproduction 126 415-424. (doi:10.1530/ rep.0.1260415)

Santos-Biase WKF, Biase FH, Buratini J Jr, Balieiro J, Watanabe YF, Accorsi MF, Ferreira CR, Stranieri P, Caetano AR \& Meirelles FV 2012 Single nucleotide polymorphisms in the bovine genome are associated with the number of oocytes collected during ovum pick up. Animal Reproduction Science 134 141-149. (doi:10.1016/j.anireprosci. 2012.08.017)

Sato T \& Nakamura H 2004 The Fgf8 signal causes cerebellar differentiation by activating the Ras-ERK signaling pathway. Development $\mathbf{1 3 1}$ 4275-4285. (doi:10.1242/dev.01281)

Schmitt JF, Hearn MT \& Risbridger GP 1996 Expression of fibroblast growth factor-8 in adult rat tissues and human prostate carcinoma cells. Journal of Steroid Biochemistry and Molecular Biology 57 173-178. (doi:10.1016/0960-0760(95)00259-6)

Shaul YD \& Seger R 2007 The MEK/ERK cascade: from signaling specificity to diverse functions. Biochimica et Biophysica Acta 1773 1213-1226. (doi:10.1016/j.bbamcr.2006.10.005)

Shimokawa K, Kimura-Yoshida C, Nagai N, Mukai K, Matsubara K, Watanabe H, Matsuda Y, Mochida K \& Matsuo I 2011 Cell surface heparan sulfate chains regulate local reception of FGF signaling in the mouse embryo. Developmental Cell 21 257-272. (doi:10.1016/j.devcel. 2011.06.027)

Spivak-Kroizman T, Lemmon MA, Dikic I, Ladbury JE, Pinchasi D, Huang J, Jaye M, Crumley G, Schlessinger J \& Lax I 1994 Heparin-induced oligomerization of FGF molecules is responsible for FGF receptor dimerization, activation, and cell proliferation. Cell 79 1015-1024 (doi:10.1016/0092-8674(94)90032-9) 
Steringer JP, Müller H-M \& Nickel W 2015 Unconventional secretion of fibroblast growth factor 2 - a novel type of protein translocation across membranes? Journal of Molecular Biology 427 1202-1210. (doi:10.1016/ j.jmb.2014.07.012)

Sudo N, Shimizu T, Kawashima C, Kaneko E, Tetsuka M \& Miyamoto A 2007 Insulin-like growth factor-I (IGF-I) system during follicle development in the bovine ovary: relationship among IGF-I, type 1 IGF receptor (IGFR-1) and pregnancy-associated plasma protein-A (PAPP-A). Molecular and Cellular Endocrinology 264 197-203. (doi:10.1016/j.mce.2006.10.011)

Sugiura K, Su Y-Q, Diaz FJ, Pangas SA, Sharma S, Wigglesworth K, O'Brien MJ, Matzuk MM, Shimasaki S \& Eppig JJ 2007 Oocyte-derived BMP15 and FGFs cooperate to promote glycolysis in cumulus cells. Development 134 2593-2603. (doi:10.1242/dev.006882)

Sugiura K, Su YQ, Li Q, Wigglesworth K, Matzuk MM \& Eppig JJ 2009 Fibroblast growth factors and epidermal growth factor cooperate with oocyte-derived members of the TGF $\beta$ superfamily to regulate Spry2 mRNA levels in mouse cumulus cells. Biology of Reproduction $\mathbf{8 1}$ 833-841. (doi:10.1095/biolreprod.109.078485)

Uma J, Muraly P, Verma-Kumar S \& Medhamurthy R 2003 Determination of onset of apoptosis in granulosa cells of the preovulatory follicles in the bonnet monkey (Macaca radiata): correlation with mitogenactivated protein kinase activities. Biology of Reproduction 69 1379-1387. (doi:10.1095/biolreprod.103.017897)

Usui H, Shibayama M, Ohbayashi N, Konishi M, Takada S \& Itoh N 2004 Fgf18 is required for embryonic lung alveolar development. Biochemical and Biophysical Research Communications 322 887-892. (doi:10.1016/j. bbrc.2004.07.198)

Valve E, Penttila TL, Paranko J \& Harkonen P 1997 FGF-8 is expressed during specific phases of rodent oocyte and spermatogonium development. Biochemical and Biophysical Research Communications 232 173-177. (doi:10.1006/bbrc.1997.6256)
Vernon RK \& Spicer LJ 1994 Effects of basic fibroblast growth factor and heparin on follicle-stimulating hormone-induced steroidogenesis by bovine granulosa cells. Journal of Animal Science $\mathbf{7 2}$ 2696-2702.

Yanagishita M \& Hascall VC 1983 Characterization of heparan sulfate proteoglycans synthesized by rat ovarian granulosa cells in culture. Journal of Biological Chemistry 258 12857-12864.

Yayon A, Klagsbrun M, Esko JD, Leder P \& Ornitz DM 1991 Cell surface, heparin-like molecules are required for binding of basic fibroblast growth factor to its high affinity receptor. Cell $\mathbf{6 4} 841-848$. (doi:10.1016/0092-8674(91)90512-W)

Zammit C, Coope R, Gomm JJ, Shousha S, Johnston CL \& Coombes RC 2002 Fibroblast growth factor 8 is expressed at higher levels in lactating human breast and in breast cancer. British Journal of Cancer 86 1097-1103. (doi:10.1038/sj.bjc.6600213)

Zhang K \& Ealy AD 2012 Disruption of fibroblast growth factor receptor signaling in bovine cumulus-oocyte complexes during in vitro maturation reduces subsequent embryonic development. Domestic Animal Endocrinology 42 230-238. (doi:10.1016/j.domaniend. 2011.12.006)

Zhang X, Ibrahimi OA, Olsen SK, Umemori H, Mohammadi M \& Ornitz DM 2006 Receptor specificity of the fibroblast growth factor family. The complete mammalian FGF family. Journal of Biological Chemistry 281 15694-15700. (doi:10.1074/jbc. M601252200)

Zhang K, Hansen PJ \& Ealy AD 2010 Fibroblast growth factor 10 enhances bovine oocyte maturation and developmental competence in vitro. Reproduction 140 815-826. (doi:10.1530/REP-10-0190)

Zhong W, Wang QT, Sun T, Wang F, Liu J, Leach R, Johnson A, Puscheck EE \& Rappolee DA 2006 FGF ligand family mRNA expression profile for mouse preimplantation embryos, early gestation human placenta, and mouse trophoblast stem cells. Molecular Reproduction and Development 73 540-550. (doi:10.1002/mrd.20417)

Received in final form 29 October 2015

Accepted 5 November 2015

Accepted Preprint published online 5 November 2015
(C) 2016 Society for Endocrinology Printed in Great Britain 